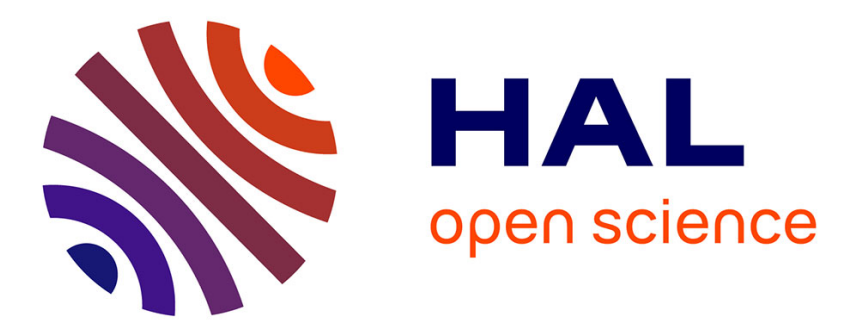

\title{
The effects of dopamine on the respiratory system: Friend or foe?
}

Agnieszka Ciarka, J.-L. Jean-Louis Vincent, Philippe van de Borne

\section{To cite this version:}

Agnieszka Ciarka, J.-L. Jean-Louis Vincent, Philippe van de Borne. The effects of dopamine on the respiratory system: Friend or foe?. Pulmonary Pharmacology \& Therapeutics, 2007, 20 (6), pp.607. 10.1016/j.pupt.2006.10.011 . hal-00499141

\section{HAL Id: hal-00499141 https://hal.science/hal-00499141}

Submitted on 9 Jul 2010

HAL is a multi-disciplinary open access archive for the deposit and dissemination of scientific research documents, whether they are published or not. The documents may come from teaching and research institutions in France or abroad, or from public or private research centers.
L'archive ouverte pluridisciplinaire HAL, est destinée au dépôt et à la diffusion de documents scientifiques de niveau recherche, publiés ou non, émanant des établissements d'enseignement et de recherche français ou étrangers, des laboratoires publics ou privés. 


\section{Author's Accepted Manuscript}

The effects of dopamine on the respiratory system:

Friend or foe?

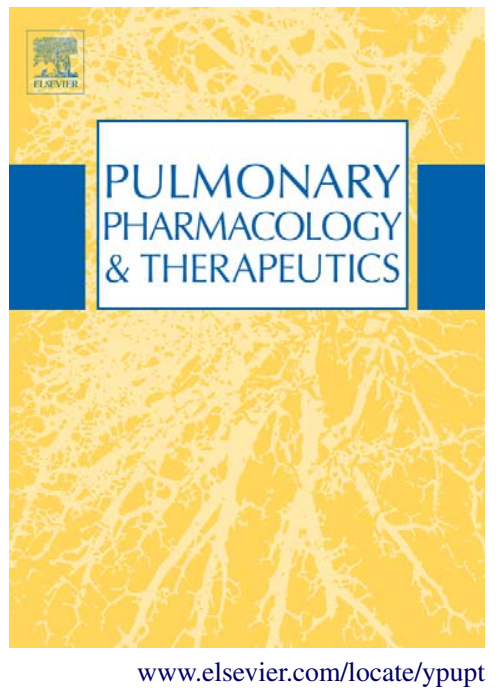

To appear in: $\quad$ Pulmonary Pharmacology \& Therapeutics

$\begin{array}{ll}\text { PII: } & \text { S1094-5539(06)00127-1 } \\ \text { DOI: } & \text { doi:10.1016/j.pupt.2006.10.011 }\end{array}$

Reference: $\quad$ YPUPT 724

Agnieszka Ciarka, Jean-Louis Vincent, Philippe van

de Borne

Received date: 25 October 2004

Revised date: 15 October 2006

Accepted date: 16 October 2006

Cite this article as: Agnieszka Ciarka, Jean-Louis Vincent and Philippe van de Borne, The effects of dopamine on the respiratory system: Friend or foe?, Pulmonary Pharmacology \& Therapeutics, doi:10.1016/j.pupt.2006.10.011

This is a PDF file of an unedited manuscript that has been accepted for publication. As a service to our customers we are providing this early version of the manuscript. The manuscript will undergo copyediting, typesetting, and review of the resulting galley proof before it is published in its final citable form. Please note that during the production process errors may be discovered which could affect the content, and all legal disclaimers that apply to the journal pertain. 
The effects of dopamine on the respiratory system:

Friend or foe?

Agnieszka Ciarka $^{1}$, Jean-Louis Vincent ${ }^{2}$, Philippe van de Borne ${ }^{1}$

${ }^{1}$ Cardiology Department, and ${ }^{2}$ Department of Intensive Care, Erasme University Hospital, Free University of Brussels, Belgium

\section{Corresponding author:}

Agnieszka Ciarka

Cardiology Department

Erasme Hospital

808 Route de Lennik

1070 Brussels

Belgium

Ph: 0032/2/5553275

Fax: 0032/2/5556813

email: aciarka@ulb.ac.be 


\section{Abstract}

Dopamine (DA) is an immediate precursor of noradrenaline that has stimulatory or inhibitory effects on a variety of adrenergic receptors. DA is primarily used in the management of circulatory shock for its combined vasopressor and inotropic effects, but it may also exert significant effects on the respiratory system Although the respiratory effects of intravenous DA attract less attention than its hemodynamic effects, there is evidence that DA affects ventilation, pulmonary circulation, bronchial diameter, neuromodulation of sensory pulmonary nerves and lung water clearance. Through these complex mechanisms, DA may exert beneficial as well as detrimental effects on respiration.

DA may have beneficial effects on the respiratory system by decreasing oedema formation and improving respiratory muscle function, but can also have deleterious effects, by inhibiting ventilation. Hence, DA may be beneficial in lung oedema, but harmful in cases of difficult weaning from mechanical ventilation. DA should be used with caution in patients with heart failure during weaning from mechanical respiration, however, critically ill patients with chronic obstructive pulmonary disease (COPD) do not show this negative effect of DA on ventilatory drive. 


\section{Introduction}

Dopamine (DA) is an immediate metabolic precursor of noradrenaline and adrenaline [1]. It has an intrinsic capacity to activate peripheral adrenergic and dopaminergic receptors [1]. In physiologic conditions, DA increases cardiac output and aortic pressure, reduces renal vascular resistance and increases glomerular filtration rate and urinary output [2]. At low doses ( $5 \mu \mathrm{g} / \mathrm{kg} / \mathrm{min})$, which do not have important hemodynamic effects, DA causes modest diuresis [3]. DA is used in patients suffering from circulatory shock (primarily septic and cardiogenic) [4], for its combined inotropic and vasopressor effects. Although the dopaminergic actions may theoretically be beneficial for renal function, the renal protective effects of DA are seriously questioned and there is ongoing discussion about the place of DA in the intensive care unit [5].

DA can exert various effects on the respiratory system (Table 1). First, DA has an established role in the control of ventilation. Dopaminergic receptors are located pre- and postsynaptically on the carotid glomus cells [6] and high concentrations of DA have been measured in the carotid bodies [7]. DA inhibits the chemosensory discharge rate in various animal species and there is clearcut evidence from animal and human studies that low dose DA infusion decreases the ventilatory response to hypoxia [8-15]. Second, DA provokes a reduction in arterial oxygen saturation at a given alveolar oxygen tension by impairing regional ventilation/perfusion matching in the lung [16]. When administered to patients with circulatory failure, DA may be deleterious for ventilation and pulmonary gas exchange, especially in hypoxemic patients with compromised respiratory function [17]. Third, DA can also reduce pulmonary vascular resistance, resulting in a decrease in pulmonary hypertension [18-22]. Fourth, DA may promote lung oedema clearance by activation of epithelial $\mathrm{Na}+/ \mathrm{K}+-\mathrm{ATPase}$ [23-27] and epithelial sodium channels [28]. Fifth, DA is involved in the regulation of airway diameter [29-31] and in neuromodulation of pulmonary sensory nerves [32, 33].

These effects have primarily been tested in animal studies. There is some clinical evidence that dopamine may improve respiratory muscle function in respiratory failure [34]. A randomised, placebocontrolled human study, based on the observation that DA receptor activation inhibits rapidly adapting stretch receptors in the lungs, gave disappointing results. Indeed, the DA-2 and beta2 adrenergic 
receptor agonist, sibenadet, did not alleviate breathlessness, cough or excess sputum in patients with chronic obstructive pulmonary disease (COPD) $[35,36]$.

This paper focuses on the effects of DA on the respiratory system, to evaluate whether DA can be safely used in acutely ill patients with respiratory failure.

\section{Clinical pharmacology}

DA exerts complex actions on peripheral and central adrenergic and dopaminergic receptors [37]. In the peripheral nervous system, DA is present in postganglionic sympathetic nerve endings and is an immediate precursor of noradrenaline. Intravenous DA does not cross the brain-blood barrier, so that it does not have central effects.

The different pharmacological actions of DA are effected through dose-dependent activation of $\alpha$-adrenergic, $\beta$-adrenergic and dopaminergic receptors. Activation of $\beta_{1}, \beta_{2}$, and $\alpha_{1}$ adrenergic receptors in the heart results in an increase in heart rate and contractility, while activation of presynaptic $\alpha_{2}$ receptors has an inhibitory effect on further release of noradrenaline from nerve terminals. In the vasculature, the activation of postsynaptic $\alpha_{1}$ and $\alpha_{2}$ receptors mediates vasoconstriction, while $\beta_{2}$ receptors mediate vasodilatation. Peripheral DA receptors belong to two classes. The DA-1 receptors activate adenyl cyclase, with a consequent increase in intracellular cAMP, while DA-2 receptors inhibit adenyl cyclase and result in activation of $\mathrm{K}+$ channels, inhibition of $\mathrm{Ca}^{2+}$ channels, and the exchange of phospatidyl inositol. DA-1 receptors provoke renal, coronary, and mesenteric vasodilatation and a natriuretic response. Stimulation of DA-2 receptors is associated with noradrenaline release from sympathetic nerve endings and inhibition of prolactin release.

DA influences these receptors in a dose dependent manner. Low doses of DA $(1-2 \mu \mathrm{g} / \mathrm{kg} / \mathrm{min})$ act primarily on the DA-1 receptors, resulting in selective vasodilatation in the renal, mesenteric, cerebral, and coronary beds. Vasodilatation can be balanced by an increase in stroke volume, so that arterial pressure remains relatively stable. Higher doses $(2-5 \mu \mathrm{g} / \mathrm{kg} / \mathrm{min})$ activate not only the dopaminergic but also the $\beta$-adrenergic receptors, resulting in increased cardiac output, due to combined increases in stroke volume and heart rate [38]. Doses of $5-10 \mu \mathrm{g} / \mathrm{kg} / \mathrm{min}$ have predominant $\beta$-adrenergic effects and start to have $\alpha$-adrenergic effects, resulting in combined increases in cardiac 
output and blood pressure. Higher doses $(10-20 \mu \mathrm{g} / \mathrm{kg} / \mathrm{min})$ provoke a predominantly $\alpha$-adrenergic activation, with vasoconstriction and increased systemic vascular resistance. The dose-dependent effects of DA are, however, not entirely predictable because of significant interindividual variability in enzymatic DA inactivation. In practical terms, DA should be titrated to a desired physiologic effect, because weight-based administration of DA can achieve quite different concentrations among individuals [39].

Although the respiratory effects of intravenous DA have attracted less attention than its hemodynamic actions, there is evidence that DA affects ventilation [16, 40-47], pulmonary circulation [18-22], bronchial diameter [29-31], neuromodulation of sensory pulmonary nerves [32, 33], and lung water clearance [23-28]. The exact mechanisms of certain pulmonary actions of DA are not entirely understood. Recently, DA-2 and DA-1 receptors were identified in the lung arteries. Interestingly, these receptors were found within the tunica adventitia in human pulmonary arteries and within the tunica media of large and medium sized intrapulmonary arteries of the rabbit [48-53]. No dopaminergic receptor has been found in the bronchial tree yet, despite the described bronchodilating action of DA in healthy subjects during histamine administration [31]. Studies on mechanisms of lung water clearance have shown that in alveolar cells, DA increases the activity of basolateral Na-KATPase and the activity of epithelial sodium channels [24, 28]. DA-1 and DA-2 receptors have been found in the carotid bodies of experimental animals [54, 55], providing an argument for a modulatory role of DA in the control of ventilation.

\section{Clinical use}

DA is primarily used for its vasopressor and inotropic actions in the management of critically ill patients with circulatory failure $[4,56]$. By combined beta-adrenergic and dopaminergic effects, low doses of DA (typically $<5 \mu \mathrm{g} / \mathrm{kg} / \mathrm{min}$ ) can decrease renal vascular resistance, increase renal blood flow, glomerular filtration rate and sodium excretion in animals and healthy humans [2]. However, the renal protective effects of DA have not been demonstrated in critically ill humans and randomised control trials did not provide direct proof that DA confers protection from renal dysfunction in critically ill patients at risk of renal failure[5]. Furthermore, the place of DA as a therapeutic agent is 
debated $[57,58]$, with many clinicians prefering the use of noradrenaline with or without dobutamine in the treatment of shock states [59].

DA is not used clinically for its effects on respiration. Neverthless, it does exert effects on the respiratory system, including depression of ventilatory drive, change in bronchial diameter, and increase in lung water clearance, which will be discussed further.

\section{THE EFFECTS OF DOPAMINE ON RESPIRATORY FUNCTION}

\section{Effects on respiration}

Respiration is largely regulated by chemoreflex mechanisms [60]. Peripheral chemoreceptors located in the carotid bodies respond primarily to hypoxia and provoke an increase in sympathetic nerve activity [61] and ventilation [62]. Human and animal type I cells (glomus cells) of the carotid bodies contain abundant quantities of DA [63-67], with a 5 to 1 ratio of DA to noradrenaline [68]. DA intervenes in the regulation of respiration not only at the level of the carotid bodies, but it is also present in the neurons of the nucleus tractus solitarius, where afferents from the carotid bodies end [55, 69]. Hypoxia increases carotid body tyrosine hydroxylase activity [70], resulting in increased DA synthesis [71] and release [8], which suggests that DA can play a role in the regulation of ventilation. In addition, many studies in animals and healthy humans have demonstrated that low dose DA is associated with decreased carotid sinus drive and diminished ventilatory response to hypoxia. In healthy subjects, low dose DA blunts the ventilatory response to isocapnic $[14,15]$ and hypercapnic [13] hypoxia, an effect which is abolished by the dopaminergic receptor blocker, haloperidol [72].

These effects of DA on respiration can be detrimental in seriously ill patients with limited breathing reserve. This detrimental effect has been shown in patients with heart failure, where low dose DA decreased minute ventilation by more than $1 \mathrm{~L} /$ min during normoxic breathing; this did not occur in age-matched control subjects[17]. Heart failure patients often have only mild arterial blood oxygen desaturation as a result of low cardiac output and pulmonary vascular congestion. DA also impairs regional ventilation/perfusion matching in the lungs [73]. Thus, there are two synergistic 
mechanisms which can affect ventilation in heart failure: first, direct impairment of gas exchange [73], and second, impaired compensatory ventilation [17]. Both mechanisms can be counterbalanced by the administration of supplemental oxygen [74] so that these effects of DA would not have important consequences, especially in mechanically ventilated patients. Sleep disordered breathing, frequently observed in patients with heart failure $[75,76]$, could be another factor contributing to the detrimental actions of DA in these patients. During sleep, central and obstructive apnoeas decrease arterial oxygen saturation and this may play a pivotal role in the genesis of cardiac arrhythmias. Both hypoxia and hypercapnia activate chemoreceptors [77] and induce short lasting arousals that terminate obstructive apnoeas. Chemoreflex inhibition by DA could be particularly deleterious in this condition, as endapnoeic desaturations, combined with potential DA arrhythmogenicity, could promote life-threatening arrhythmias.

In patients with heart failure, DA may have dual effects during weaning from mechanical ventilation. Patients receiving DA would experience reduced discomfort associated with hypoxia, but DA would further decrease ventilatory drive and diminish arterial blood oxygen saturation[17], with the potential danger of precipitating respiratory failure and problems during weaning from mechanical ventilation.

We recently investigated the possible impact of DA on weaning from mechanical ventilation in patients with COPD [78]: we observed that DA did not attenuate ventilation and had no effect on arterial blood gases [78]. This discrepancy between patients with COPD and those with heart failure may be explained by differences in the peripheral chemoreceptor drive for ventilation, which is reduced $[79,80]$ in COPD patients and heightened in patients with heart failure [81]. We speculate that the low peripheral chemoreceptor drive cannot be further inhibited in COPD, and therefore DA cannot further decrease ventilatory drive in these patients.

\section{Effects on the respiratory muscles}

Improvement in blood flow can increase the force of contraction of the respiratory muscles, and an early study suggested that DA may improve diaphragmatic function in COPD patients [34]. 


\section{Effects on the pulmonary circulation}

DA can reduce pulmonary vascular tone and thus decrease pulmonary hypertension [18-22]. This has been shown in patients with COPD [82]. Several mechanisms have been proposed. First, DA1 receptors are present in the tunica intima and media of large and medium pulmonary arteries, while DA-2 receptors are found in the adventitia of extrapulmonary arteries and in medium and large intrapulmonary arteries. All these findings were made using histochemical techniques [49-53], while in situ hybridisation further confirms the presence of DA-1 receptors in the tunica media of the aorta and the pulmonary artery [48]. Second, dopaminergic receptors may also induce vasodilation through relaxation of the pulmonary endothelium.

\section{Effects on extravascular lung water}

Pulmonary oedema can be viewed as an imbalance between the biological mechanisms that drive water into the alveolar space and the forces assuring its removal. It can result from a change in the hydrostatic and/or oncotic pressure gradients across the pulmonary circulation or from increased alveolar permeability.

Several studies have reported that DA can increase lung oedema clearance by increasing active sodium transport (via epithelial Na/K-ATP-ase stimulation). In rats, experiments with DA were performed using three different models of pulmonary oedema (hyperoxia, mechanical ventilation with high tidal volume, and increase in hydrostatic pressure). DA increased lung oedema clearance in rats breathing room air and rats exposed to $100 \%$ oxygen (such exposure to oxygen results in severe lung injury and death due to respiratory failure) [26]. Moreover, rat alveolar type II cells incubated with DA present abundant quantities of the alphal subunit protein of Na K-ATPase in the basolateral membranes, indicating that DA may recruit Na pumps from intracellular pools [26]. In line with this hypothesis, colchicine, which inhibits the microtubular transport system, blocks the stimulatory effect of DA on active $\mathrm{Na}+$ transport [26]. The same effect of DA on lung oedema clearance was observed in an isolated perfused lung rat model, where ouabain, a specific inhibitor of Na K-ATP-ase, abolished 
the dose dependent increase in liquid clearance exerted by DA [23]. Furthermore, it was demonstrated that the lung oedema clearance was mediated by D1 receptor activation [24].

Sznajder and co-workers developed an animal model of lung oedema, induced by mechanical ventilation with high tidal volume, with resulting impairment of active $\mathrm{Na}+$ transport and lung liquid clearance [25]. In this model, DA increased alveolar fluid reabsorption in nonventilated control rats by $60 \%$, rats ventilated with low tidal volume by $55 \%$ and rats ventilated with high tidal volume by 200 $\%$ [27]. These effects of DA were abolished by administration of colchicine, which supports previous observations that DA increases $\mathrm{Na}+-\mathrm{K}+-\mathrm{ATPase}$ mobilisation from the intracellular pool [27].

Finally, there are studies on the effects of DA in animal models of hydrostatic pulmonary oedema, where active $\mathrm{Na}+$ transport and alveolar fluid reabsorption are decreased [83]. Similar to other reports on different models of lung oedema, DA increased alveolar fluid reabsorption in isolated rat lungs with increased left atrial pressure, and this effect was abolished by the administration of the specific D1 receptor antagonist, ouabain (a Na K-ATPase inhibitor) and colchicine [84].

In contrast to these studies, Tibayan et al failed to show that DA given intravenously (5-10 $\mu \mathrm{g} / \mathrm{kg} / \mathrm{min}$ ), or intra-alveolarly (10-4 M), affected alveolar liquid clearance [85], while dobutamine increased alveolar liquid clearance by $50 \%$. Moreover, this effect was abolished by a potent and specific beta 2 receptor blocker [85]. This results are in line with the hypothesis that alveolar epithelial sodium transport is mediated by beta 2 receptor stimulation [85].

\section{Effects on the airways}

There is growing evidence that DA is involved in the regulation of airway diameter. The control of the bronchial diameter by the autonomic nervous system is highly complex and involves neural and humoral factors [86]. Adrenergic and cholinergic systems are involved in this regulation, as well as inhibitory and excitatory non-adrenergic, non-cholinergic nerves (i-NANC/e-NANC) [87]. Adrenergic control is carried out by the release of noradrenaline from the nerve endings and by the release of adrenaline from the adrenal medulla. Adrenaline and noradrenaline can produce bronchodilation by the stimulation of $\beta 2$ adrenergic receptors, but they can also cause bronchoconstriction, by stimulation of $\alpha 1$ and $\alpha 2$ adrenergic receptors, if pathological disturbances 
exist in the airways [88]. Non-adrenergic/non-cholinergic nervous control of airway smooth muscle is exerted by neurotransmitters, such as substance P and neurokinin A (contraction of the airway smooth muscle) and neuropeptide Y (relaxation of the neural smooth muscle) [89]. Thus, local reflexes regulate airway diameter through nerves that release neuropeptides as well as by other substances released by epithelial and interstitial cells $[90,91]$. Some studies have demonstrated that DA may also exert a modulatory role on airway diameter. DA inhibits the bronchoconstriction produced by increasing doses of histamine, infused or inhaled in healthy subjects as well as in bronchospastic patients (Table 2) [31]. However, DA had no effect on the bronchial tree when administered to subjects with a history of bronchial asthma but no bronchospasm at the time of the investigation (Table 2) $[89,92]$. Moreover, the DA2 receptor blocker, metoclopramide, had no effect on asthmatic patients without bronchospasm (Table 2) [89]. One animal study reported that it is possible to inhibit bronchcoconstriction induced by electrical field stimulation and this effect may be prevented by blocking DA1 receptors [30].

No DA receptor has yet been identified in the human bronchial tree. However, one recent animal study reported that stimulation of DA2 receptors by a compound similar to DA produces a bronchodilatatory effect on the airways in dogs and guinea pigs [29].

Thus, DA could be potentially beneficial in clinical states associated with bronchoconstriction, but further randomised, placebo controlled clinical studies are needed to investigate its potential to alleviate bronchospasm in humans.

DA may also act by neuromodulation of pulmonary sensory nerves. Sensory nerve fibres in the airways control events such as bronchoconstriction, airway plasma leakage and cough [93]. There are two classes of sensory nerve fibres, which control sensory nerve reflexes: myelinated, rapidly adapting stretch receptors (RARs) and non-myelinated, C-fibres [93]. RARs are located along the entire tracheobronchial tree and are activated by chemical (histamine), mechanical, and osmotic stimuli [94]. They elicit defensive actions such as cough, mucus production, and rapid shallow breathing [94]. Activation of myelinated as well as non myelinated fibres, elicits cough, bronchoconstriction and mucus secretion via an afferent central reflex pathway $[95,96]$. 
DA2 receptor mRNA is present in the sensory ganglia of rat airways [33]. It has been demonstrated that DA receptor activation inhibits RAR activation in vivo [32] and inhibits neuropeptide release from the peripheral endings of airway sensory neurons [33]. In dogs pretreated with propranolol and phentolamine (to prevent the $\beta$ and the $\alpha$ adrenergic effects of DA, respectively), DA infusion inhibited histamine-induced stimulation of RARs [32]. This action was prevented by the DA-2 antagonist, sulpiride [32].

It was, therefore, postulated that DA receptor agonists would alleviate the debilitating symptoms of COPD, and this hypothesis was tested in a randomised, placebo controlled trial, which is discussed later.

\section{Clinical application in COPD}

Patients with COPD present dyspnoea, cough, and excess sputum production, which decrease their quality of life [97]. The underlying mechanisms are complex, but reflex activation of sensory afferent nerves by irritants, which in the normal organism serves to clear the airways and is an important mechanism of self-defence, is known to induce these symptoms.. Since sensory RAR fibres are implicated in the control of cough, bronchospasm and sputum production [94], and DA2 receptors are present in RARs [33], and DA infusion in animal models inhibited histamine-induced activation of RARs [94], it has been suggested that the dual DA-2 and $\beta_{2}$ receptor agonist, sibenadet, could have beneficial effects on debilitating symptoms in COPD patients [36, 94]. Although the role of beta2 receptor blockers has been well established in the treatment of COPD, dopamine agonism is a completely new approach in this disease.

An initial study [35] aimed to compare the effects of sibenadet, placebo and common bronchodilator therapies (salbutamol and ipratropium bromide) on key symptoms of COPD evaluated by the Breathlessness, Cough and Sputum Scale (BCSS) [98]. This patient-reported scale is a validated and reliable outcome measure of symptom severity [98]. Early clinical evaluation of sibenadet was very promising [35]. Sibenadet improved the symptoms of breathlessness, cough and sputum in this 28-day trial, while standard bronchodilators provided only limited symptomatic improvement [35]. The positive effects of sibenadet were dose-related, and the dose of $500 \mu \mathrm{g}$, delivered in two equal 
fractions, proved to have the highest efficacy without compromising safety, and was subsequently used in large scale studies [36].

However, long term studies have not supported a clinical benefit of sibenadet on the symptoms of COPD [36]. The efficacy of sibenadet (at a dose $500 \mu \mathrm{g}$ ) in comparison with placebo was assessed in studies of 3- and 6-month duration. The primary endpoints were defined as changes in BCSS and forced expiratory volume in one second (FEV1) from baseline. Health-related quality of life, perception of treatment efficacy and adverse effects were also recorded. Although there was an immediate reduction in BCSS at the beginning of the study, there was a gradual increase in symptom scores among the patients treated with sibenadet, in comparison to placebo. By the end of the study, the differences in BCSS between the placebo and sibenadet group were not statistically significant. The fact that initial improvements in symptomatology tailed off over time, could reflect a tolerance phenomenon. FEV1 measurement clearly demonstrated a significant improvement in the sibenadet group, which was attributed to the vasodilatatory effects of the drug. However, the magnitude of these increases diminished over time, which could be attributed to tachyphylaxis, a recognised potential effect of regular b2-agonist use. No significant difference between the two groups was detected in the health-related quality of life score, although a higher proportion of investigators and patients rated sibenadet as more effective than placebo. The proportion of patients experiencing at least one exacerbation was similar in placebo and sibenadet groups. There was no difference in the frequency of adverse effects between the placebo and sibenadet groups and a 1-year safety study also demonstrated that sibenadet was well tolerated [99].

Therefore, despite encouraging preclinical and early clinical data, the long-term clinical trial demonstrated that sibenadet does not provide long-term symptomatological benefit. One possible explanation is that early symptomatic benefit was beta2 rather than D2 driven and diminished secondary to tachyphylaxis. Moreover, it is possible that beta2 tachyphylaxis diminished dual beta2/D2 actions and masked such mechanisms as dopamine2 receptor agonism on the cough component [99].

\section{Conclusions}


In summary, DA is still used in the intensive care unit for its vasopressor and inotropic effects, combined with dopaminergic effects that may protect renal and splanchnic blood flow. DA can also have both favourable and detrimental effects on pulmonary function. Low dose DA can depress ventilation in patients with heart failure, thus it must be used cautiously in these patients during weaning from mechanical ventilation. However, DA is safe in patients with COPD, because it did not alter ventilation either in patients during weaning, or in hypoxemic, spontaneously breathing COPD patients.

Some anecdotal reports show that DA can improve diaphragmatic function and respiratory muscle contraction, as well as decrease pulmonary hypertension in COPD. Nevertheless, no placebo controlled, randomised trial, has been conducted to confirm these observations.

DA has potentially beneficial effects on the respiratory system, such as an increase in lung oedema clearance or inhibition of bronchoconstriction. However, the impact of DA on lung oedema has not been tested in human studies and clinical trials on the effects of DA on airway diameter have proved disappointing, unless administered during an acute asthmatic exacerbation.

Finally, the dopaminergic receptor agonist, sibenadet, did not induce sustained clinical benefits in patients with COPD, despite evidence from animal studies that DA inhibits sensory nerve fibres (activation of which elicits cough, bronchoconstriction and mucus production).

Thus, despite many years of widespread use, the role of dopaminergic support in respiratory disease remains poorly defined. We lack direct, convincing human studies in favour of DA's beneficial effects on the respiratory system, but we have evidence of a detrimental impact of low dose DA on ventilation in healthy humans and patients with heart failure. DA should, therefore, be used with caution in critically ill hypoxemic patients during weaning from mechanical ventilation. 
Reference List

[1]. Hardman,J.G., Limbrid,L.E., Molinoff,P.B., Ruddon,R.W., and Gilman,A.G. (1996):

Goodman and Gilman's The Pharmacological Basis of Therapeutics.

[2]. MCDONALD RH, Jr., Goldberg LI, MCNAY JL, TUTTLE EP, Jr. EFFECT OF DOPAMINE IN MAN: AUGMENTATION OF SODIUM EXCRETION, GLOMERULAR FILTRATION RATE, AND RENAL PLASMA FLOW. J Clin Invest 1964; 43:1116-1124.

[3]. Varriale P, Mossavi A. The benefit of low-dose dopamine during vigorous diuresis for congestive heart failure associated with renal insufficiency: does it protect renal function? Clin Cardiol 1997; 20:627-630.

[4]. Goldberg LI. Dopamine--clinical uses of an endogenous catecholamine. N Engl J Med 1974; 291:707-710.

[5]. Holmes CL, Walley KR. Bad medicine: low-dose dopamine in the ICU. Chest 2003; $123: 1266-1275$

[6]. Mir AK, McQueen DS, Pallot DJ, Nahorski SR. Direct biochemical and neuropharmacological identification of dopamine D2-receptors in the rabbit carotid body. Brain Res 1984; 291:273-283.

[7]. Fidone SJ, Gonzalez C, Yoshizaki K. Putative neurotransmitters in the carotid body: the case for dopamine. Fed Proc 1980; 39:2636-2640. 
[8]. Hanbauer I, Hellstrom S. The regulation of dopamine and noradrenaline in the rat carotid body and its modification by denervation and by hypoxia. J Physiol $1978 ; 282: 21-34$

[9]. Ide T, Shirahata M, Chou CL, Fitzgerald RS. Effects of a continuous infusion of dopamine on the ventilatory and carotid body responses to hypoxia in cats. Clin Exp Pharmacol Physiol 1995; 22:658-664.

[10]. Lahiri S, Nishino T, Mokashi A, Mulligan E. Interaction of dopamine and haloperidol with O2 and CO2 chemoreception in carotid body. J Appl Physiol 1980; 49:45-51.

[11]. Llados F, Zapata P. Effects of dopamine analogues and antagonists on carotid body chemosensors in situ. J Physiol 1978; 274:487-499.

[12]. Nishino T, Lahiri S. Effects of dopamine on chemoreflexes in breathing. J Appl Physiol 1981; 50:892-897.

[13]. Olson LG, Hensley MJ, Saunders NA. Ventilatory responsiveness to hypercapnic hypoxia during dopamine infusion in humans. Am Rev Respir Dis 1982; $126: 783-787$.

[14]. Ward DS, Bellville JW. Reduction of hypoxic ventilatory drive by dopamine. Anesth Analg 1982; 61:333-337.

[15]. Welsh MJ, Heistad DD, Abboud FM. Depression of ventilation by dopamine in man. Evidence for an effect on the chemoreceptor reflex. J Clin Invest 1978; 61:708713. 
[16]. Huckauf H, Ramdohr B, Schroder R. Dopamine induced hypoxemia in patients with left heart failure. Int J Clin Pharmacol Biopharm 1976; 14:217-224.

[17]. van de Borne P, Oren R, Somers VK. Dopamine depresses minute ventilation in patients with heart failure. Circulation 1998; 98:126-131.

[18]. Gorman P. Vasodilator response to dopamine in the ferret pulmonary circulation. Br J Pharmacol 1988; 94:212-218.

[19]. Loick HM, Traber LD, Tokyay R, Theissen JL, Linares HA, Traber DL. The effect of dopamine on pulmonary hemodynamics and tissue damage after inhalation injury in an ovine model. J Burn Care Rehabil 1992; 13:305-315.

[20]. McCormack DG, Barnes PJ, Evans TW. Effects of dopexamine hydrochloride on hypoxic pulmonary vasoconstriction in isolated rat lung. Crit Care Med 1990; 18:520-523.

[21]. Polak MJ, Knight ME, Gause GE, Bucciarelli RL, Drummond W. Effect of fenoldopam on preconstricted isolated salt-perfused rat lungs. J Appl Physiol $1989 ; 67: 1076-1080$.

[22]. Polak MJ, Kennedy LA, Drummond WH. Manipulation of dopamine receptors alters hypoxic pulmonary vasoconstriction in isolated perfused rat lungs. Life Sci 1992; 51:1317-1323.

[23]. Barnard ML, Olivera WG, Rutschman DM, Bertorello AM, Katz AI, Sznajder JI. Dopamine stimulates sodium transport and liquid clearance in rat lung epithelium. Am J Respir Crit Care Med 1997; 156:709-714. 
[24]. Barnard ML, Ridge KM, Saldias F, Friedman E, Gare M, Guerrero C, Lecuona E, Bertorello AM, Katz AI, Sznajder JI. Stimulation of the dopamine 1 receptor increases lung edema clearance. Am J Respir Crit Care Med 1999; 160:982986.

[25]. Lecuona E, Saldias F, Comellas A, Ridge K, Guerrero C, Sznajder JI. Ventilatorassociated lung injury decreases lung ability to clear edema in rats. Am J Respir Crit Care Med 1999; 159:603-609.

[26]. Saldias FJ, Lecuona E, Comellas AP, Ridge KM, Sznajder JI. Dopamine restores lung ability to clear edema in rats exposed to hyperoxia. Am J Respir Crit Care Med $1999 ; 159: 626-633$.

[27]. Saldias FJ, Comellas AP, Pesce L, Lecuona E, Sznajder JI. Dopamine increases lung liquid clearance during mechanical ventilation. Am J Physiol Lung Cell Mol Physiol 2002; 283:L136-L143.

[28]. Helms MN, Chen XJ, Ramosevac S, Eaton DC, Jain L. Dopamine regulation of amiloride-sensitive sodium channels in lung cells. Am J Physiol Lung Cell Mol Physiol 2006; 290:L710-L722.

[29]. Bonnert RV, Brown RC, Chapman D, Cheshire DR, Dixon J, Ince F, Kinchin EC, Lyons AJ, Davis AM, Hallam C, Harper ST, Unitt JF, Dougall IG, Jackson DM, McKechnie K, Young A, Simpson WT. Dual D2-receptor and beta2adrenoceptor agonists for the treatment of airway diseases. 1. Discovery and biological evaluation of some 7-(2-aminoethyl)-4-hydroxybenzothiazol-2(3H)one analogues. J Med Chem 1998; 41:4915-4917. 
[30]. Kamikawa Y, Shimo Y. Inhibitory effects of catecholamines on cholinergically and non-cholinergically mediated contractions of guinea-pig isolated bronchial muscle. J Pharm Pharmacol 1990; 42:131-134.

[31]. Michoud MC, Amyot R, Jeanneret-Grosjean A. Dopamine effect on bronchomotor tone in vivo. Am Rev Respir Dis 1984; 130:755-758.

[32]. Jackson DM, Simpson WT. The effect of dopamine on the rapidly adapting receptors in the dog lung. Pulm Pharmacol Ther 2000; 13:39-42.

[33]. Peiser C, Trevisani M, Groneberg DA, Dinh QT, Lencer D, Amadesi S, Maggiore B, Harrison S, Geppetti P, Fischer A. Dopamine type 2 receptor expression and function in rodents sensory neurons projecting to the airways. Am J Physiol Lung Cell Mol Physiol 2005.

[34]. Aubier M, Murciano D, Menu Y, Boczkowski J, Mal H, Pariente R. Dopamine effects on diaphragmatic strength during acute respiratory failure in chronic obstructive pulmonary disease. Ann Intern Med 1989; 110:17-23.

[35]. Ind PW, Laitinen L, Laursen L, Wenzel S, Wouters E, Deamer L, Nystrom P. Early clinical investigation of Viozan (sibenadet $\mathrm{HCl}$ ), a novel D2 dopamine receptor, beta2-adrenoceptor agonist for the treatment of chronic obstructive pulmonary disease symptoms. Respir Med 2003; 97 Suppl A:S9-21.

[36]. Laursen LC, Lindqvist A, Hepburn T, Lloyd J, Perrett J, Sanders N, Rocchiccioli K. The role of the novel D2/beta2-agonist, Viozan (sibenadet $\mathrm{HCl}$ ), in the treatment of symptoms of chronic obstructive pulmonary disease: results of a large-scale clinical investigation. Respir Med 2003; 97 Suppl A:S23-S33. 
[37]. Rudis MI, Basha MA, Zarowitz BJ. Is it time to reposition vasopressors and inotropes in sepsis? Crit Care Med 1996; 24:525-537.

[38]. Lollgen H, Drexler H. Use of inotropes in the critical care setting. Crit Care Med 1990; 18:S56-S60.

[39]. MacGregor DA, Smith TE, Prielipp RC, Butterworth JF, James RL, Scuderi PE. Pharmacokinetics of dopamine in healthy male subjects. Anesthesiology 2000; 92:338-346.

[40]. Hanbauer I, Hellstrom S. The regulation of dopamine and noradrenaline in the rat carotid body and its modification by denervation and by hypoxia. J Physiol $1978 ; 282: 21-34$

[41]. Ide T, Shirahata M, Chou CL, Fitzgerald RS. Effects of a continuous infusion of dopamine on the ventilatory and carotid body responses to hypoxia in cats. Clin Exp Pharmacol Physiol 1995; 22:658-664.

[42]. Lahiri S, Nishino T, Mokashi A, Mulligan E. Interaction of dopamine and haloperidol with $\mathrm{O} 2$ and CO2 chemoreception in carotid body. J Appl Physiol 1980; $49: 45-51$

[43]. Llados F, Zapata P. Effects of dopamine analogues and antagonists on carotid body chemosensors in situ. J Physiol 1978; 274:487-499.

[44]. Nishino T, Lahiri S. Effects of dopamine on chemoreflexes in breathing. J Appl Physiol 1981; 50:892-897.

[45]. Olson LG, Saunders NA. Effect of a dopamine antagonist on ventilation during sustained hypoxia in mice. J Appl Physiol 1987; 62:1222-1226. 
[46]. Ward DS, Bellville JW. Reduction of hypoxic ventilatory drive by dopamine. Anesth Analg 1982; 61:333-337.

[47]. Welsh MJ, Heistad DD, Abboud FM. Depression of ventilation by dopamine in man. Evidence for an effect on the chemoreceptor reflex. J Clin Invest 1978; 61:708713.

[48]. Kim MO, Koh PO, Kim JH, Kim JS, Kang SS, Cho GJ, Kim K, Choi WS. Localization of dopamine D1 and D2 receptor mRNAs in the rat systemic and pulmonary vasculatures. Mol Cells 1999; 9:417-421.

[49]. Kobayashi Y, Ricci A, Amenta F. Autoradiographic localization of dopamine D1-like receptors in the rabbit pulmonary circulation. Eur J Pharmacol 1994; 253:201206.

[50]. Kobayashi Y, Cavallotti D, Ricci A, Amenta F. Localisation of dopamine D2-like receptors in pulmonary artery of the human and rabbit but not of the rat. Eur $\mathrm{J}$ Pharmacol 1994; 261:229-236.

[51]. Kobayashi Y, Ricci A, Rossodivita I, Amenta F. Autoradiographic localization of dopamine D2-like receptors in the rabbit pulmonary vascular tree. Naunyn Schmiedebergs Arch Pharmacol 1994; 349:559-564.

[52]. Kobayashi Y, Ricci A, Amenta F, Cavallotti C, Hattori K. Localization of dopamine receptors in the rabbit lung vasculature. J Vasc Res 1995; 32:200-206.

[53]. Kobayashi Y, Amenta F, Ricci A, Hattori K. Localisation of dopamine D1-like and D2-like receptors in the pulmonary vasculature. Hypertens Res 1995; 18 Suppl 1:S153-S156. 
[54]. Bairam A, Frenette J, Dauphin C, Carroll JL, Khandjian EW. Expression of dopamine D1-receptor mRNA in the carotid body of adult rabbits, cats and rats. Neurosci Res 1998; 31:147-154.

[55]. Bairam A, Neji H, De Grandpre P, Carroll JL. Autoreceptor mechanism regulating carotid body dopamine release from adult and 10-day-old rabbits. Respir Physiol 2000; 120:27-34.

[56]. Goldberg LI. Cardiovascular and renal actions of dopamine: potential clinical applications. Pharmacol Rev 1972; 24:1-29.

[57]. Friedrich JO, Adhikari N, Herridge MS, Beyene J. Meta-analysis: low-dose dopamine increases urine output but does not prevent renal dysfunction or death. Ann Intern Med 2005; 142:510-524.

[58]. Debaveye YA, Van den Berghe GH. Is there still a place for dopamine in the modern intensive care unit? Anesth Analg 2004; 98:461-468.

[59]. Sakr Y, Reinhart K, Vincent JL, Sprung CL, Moreno R, Ranieri VM, De Backer D, Payen D. Does dopamine administration in shock influence outcome? Results of the Sepsis Occurrence in Acutely Ill Patients (SOAP) Study. Crit Care Med 2006; 34:589-597.

[60]. Berger AJ, Mitchell RA, Severinghaus JW. Regulation of respiration (first of three parts). N Engl J Med 1977; 297:92-97.

[61]. Somers VK, Mark AL, Zavala DC, Abboud FM. Contrasting effects of hypoxia and hypercapnia on ventilation and sympathetic activity in humans. J Appl Physiol $1989 ; 67: 2101-2106$. 
[62]. Prabhakar NR, Peng YJ. Peripheral chemoreceptors in health and disease. J Appl Physiol 2004; 96:359-366.

[63]. Chiocchio SR, Biscardi AM, Tramezzani JH. Catecholamines in the carotid body of the cat. Nature $1966 ; 212: 834-835$.

[64]. Dearnaley DP, Fillenz M, Woods RI. The identification of dopamine in the rabbit's carotid body. Proc R Soc Lond B Biol Sci 1968; 170:195-203.

[65]. Hellstrom S, Hanbauer I, Costa E. Selective decrease of dopamine content in rat carotid body during exposure to hypoxic conditions. Brain Res 1976; 118:352355.

[66]. Steele RH, Hinterberger H. Catecholamines and 5-hydroxytryptamine in the carotid body in vascular, respiratory, and other diseases. J Lab Clin Med 1972; 80:6370.

[67]. Zapata P, Hess A, Bliss EL, Eyzaguirre C. Chemical, electron microscopic and physiological observations on the role of catecholamines in the carotid body. Brain Res 1969; 14:473-496.

[68]. Vicario I, Rigual R, Obeso A, Gonzalez C. Characterization of the synthesis and release of catecholamine in the rat carotid body in vitro. Am J Physiol Cell Physiol 2000; 278:C490-C499.

[69]. Bisgard GE. Carotid body mechanisms in acclimatization to hypoxia. Respir Physiol $2000 ; 121: 237-246$.

[70]. Gonzalez C, Kwok Y, Gibb J, Fidone S. Effects of hypoxia on tyrosine hydroxylase activity in rat carotid body. J Neurochem 1979; 33:713-719. 
[71]. Fidone SJ, Gonzalez C, Yoshizaki K. Putative neurotransmitters in the carotid body: the case for dopamine. Fed Proc 1980; 39:2636-2640.

[72]. Bainbridge CW, Heistad DD. Effect of haloperidol on ventilatory responses to dopamine in man. J Pharmacol Exp Ther 1980; 213:13-17.

[73]. Shoemaker WC, Appel PL, Kram HB, Duarte D, Harrier HD, Ocampo HA. Comparison of hemodynamic and oxygen transport effects of dopamine and dobutamine in critically ill surgical patients. Chest 1989; 96:120-126.

[74]. Johnson RL, Jr. Low-dose dopamine and oxygen transport by the lung. Circulation 1998; 98:97-99.

[75]. Javaheri S. Central sleep apnea-hypopnea syndrome in heart failure: prevalence, impact, and treatment. Sleep 1996; 19:S229-S231.

[76]. Mansfield DR, Naughton MT. Sleep apnea and congestive heart failure. Minerva Med 2004; 95:257-280.

[77]. Somers VK, Mark AL, Zavala DC, Abboud FM. Contrasting effects of hypoxia and hypercapnia on ventilation and sympathetic activity in humans. J Appl Physiol $1989 ; 67: 2101-2106$

[78]. Ciarka A, Rimacchi R, Vincent JL, Velez-Roa S, Dumonceaux M, Leeman M, van de BP. Effects of low-dose dopamine on ventilation in patients with chronic obstructive pulmonary disease. Eur J Clin Invest 2004; 34:508-512.

[79]. Erbland ML, Ebert RV, Snow SL. Interaction of hypoxia and hypercapnia on respiratory drive in patients with COPD. Chest 1990; 97:1289-1294. 
[80]. Fahey PJ, Hyde RW. "Won't breathe" vs "can't breathe". Detection of depressed ventilatory drive in patients with obstructive pulmonary disease. Chest 1983; $84: 19-25$.

[81]. Ponikowski P, Chua TP, Anker SD, Francis DP, Doehner W, Banasiak W, PooleWilson PA, Piepoli MF, Coats AJ. Peripheral chemoreceptor hypersensitivity: an ominous sign in patients with chronic heart failure. Circulation 2001; 104:544-549.

[82]. Philip-Joet FF, Paganelli FF, Dutau HL, Saadjian AY. Hemodynamic effects of bilevel nasal positive airway pressure ventilation in patients with heart failure. Respiration 1999; 66:136-143.

[83]. Rutschman DH, Olivera W, Sznajder JI. Active transport and passive liquid movement in isolated perfused rat lungs. J Appl Physiol 1993; 75:1574-1580.

[84]. Azzam ZS, Saldias FJ, Comellas A, Ridge KM, Rutschman DH, Sznajder JI. Catecholamines increase lung edema clearance in rats with increased left atrial pressure. J Appl Physiol 2001; 90:1088-1094.

[85]. Tibayan FA, Chesnutt AN, Folkesson HG, Eandi J, Matthay MA. Dobutamine increases alveolar liquid clearance in ventilated rats by beta-2 receptor stimulation. Am J Respir Crit Care Med 1997; 156:438-444.

[86]. Barnes PJ. Neural control of human airways in health and disease. Am Rev Respir Dis 1986; 134:1289-1314.

[87]. Widdicombe JG. Autonomic regulation. i-NANC/e-NANC. Am J Respir Crit Care Med 1998; 158:S171-S175. 
[88]. Johnson M. The beta-adrenoceptor. Am J Respir Crit Care Med 1998; 158:S146S153.

[89]. Cabezas GA, Israili ZH, Velasco M. The actions of dopamine on the airways. Am J Ther 2003; 10:477-486.

[90]. Barnes PJ. Pharmacology of airway smooth muscle. Am J Respir Crit Care Med 1998; 158:S123-S132.

[91]. Spina D. Epithelium smooth muscle regulation and interactions. Am J Respir Crit Care Med 1998; 158:S141-S145.

[92]. Thomson NC, Patel KR. Effect of dopamine on airways conductance in normals and extrinsic asthmatics. Br J Clin Pharmacol 1978; 5:421-424.

[93]. Birrell MA, Crispino N, Hele DJ, Patel HJ, Yacoub MH, Barnes PJ, Belvisi MG. Effect of dopamine receptor agonists on sensory nerve activity: possible therapeutic targets for the treatment of asthma and COPD. Br J Pharmacol $2002 ; 136: 620-628$.

[94]. Dougall IG, Young A, Ince F, Jackson DM. Dual dopamine D2 receptor and beta2adrenoceptor agonists for the treatment of chronic obstructive pulmonary disease: the pre-clinical rationale. Respir Med 2003; 97 Suppl A:S3-S7.

[95]. Karlsson JA, Sant'Ambrogio G, Widdicombe J. Afferent neural pathways in cough and reflex bronchoconstriction. J Appl Physiol 1988; 65:1007-1023.

[96]. Karlsson JA. A role for capsaicin sensitive, tachykinin containing nerves in chronic coughing and sneezing but not in asthma: a hypothesis. Thorax 1993; 48:396400. 
[97]. Van Der Molen T, Willemse BW, Schokker S, Ten Hacken NH, Postma DS, Juniper EF. Development, validity and responsiveness of the Clinical COPD Questionnaire. Health Qual Life Outcomes 2003; 1:13.

[98]. Leidy NK, Schmier JK, Jones MK, Lloyd J, Rocchiccioli K. Evaluating symptoms in chronic obstructive pulmonary disease: validation of the Breathlessness, Cough and Sputum Scale. Respir Med 2003; 97 Suppl A:S59-S70.

[99]. Hiller FC, Alderfer V, Goldman M. Long-term use of Viozan (sibenadet HCl) in patients with chronic obstructive pulmonary disease: results of a 1-year study. Respir Med 2003; 97 Suppl A:S45-S52.

[100]. Cabezas GA, Lezama Y, Vidal A, Velasco M. Inhaled dopamine induces bronchodilatation in patients with bronchial asthma. Int J Clin Pharmacol Ther 1999; 37:510-513.

[101]. Cabezas GA, Lezama Y, Velasco M. Dopaminergic modulation of human bronchial tone. Arch Med Res 2001; 32:143-147. 
Table 1. Published beneficial and detrimental effects of dopamine in the respiratory system.

\begin{tabular}{|l|l|}
\hline Beneficial effects of dopamine & Detrimental effects of dopamine \\
\hline $\begin{array}{l}\text { decrease in pulmonary vascular } \\
\text { resistance and in pulmonary } \\
\text { hypertension }\end{array}$ & $\begin{array}{l}\text { modulation of chemosensitivity } \\
\text { and decreased ventilation in } \\
\text { hypoxic conditions }\end{array}$ \\
- $\begin{array}{l}\text { increase in lung oedema clearance } \\
\text { by activation of epithelial ATP- } \\
\text { ase and epithelial sodium } \\
\text { channels }\end{array}$ & - $\begin{array}{l}\text { increase in ventilation/perfusion } \\
\text { mismatch in the lungs }\end{array}$ \\
- improvement of diaphragmatic \\
$\begin{array}{l}\text { function in chronic obstructive } \\
\text { pulmonary disease }\end{array}$ \\
$\begin{array}{l}\text { inhibition of bronchoconstriction } \\
\text { during bronchospasm }\end{array}$ \\
$\begin{array}{l}\text { inhibition of rapidly adapting } \\
\text { stretch receptors in the lung, } \\
\text { which control sensory nerve } \\
\text { reflexes }\end{array}$
\end{tabular}


Table 2. Summary of studies on the effects of dopamine (DA) on bronchial diameter. DA was administered either intravenously or by inhalation and the effects were tested in healthy subjects, patients with a past history of asthma, and patients with acute bronchospasm. One study tested effects of the DA receptor blocker, metoclopramide, on bronchial airway diameter. (FVC $=$ forced vital capacity, FEV1 = forced expiratory volume in the first second, FEFmax = maximal forced expiratory flow, FEF $50=$ forced expiratory flow at $50 \%$ of vital capacity).

\begin{tabular}{|c|c|c|c|}
\hline Reference & Subjects and patients & Drug and dose tested & $\begin{array}{l}\text { Effects on bronchial } \\
\text { diameter }\end{array}$ \\
\hline \multirow[t]{3}{*}{$\begin{array}{l}\text { Cabezas et } \\
\text { al.[100] }\end{array}$} & $\begin{array}{l}18 \text { patients with acute } \\
\text { asthmatic attack }\end{array}$ & DA IV $0.5 \mu \mathrm{g} / \mathrm{kg} / \mathrm{min}$ & $\begin{array}{l}\text { Increased FVC by } \\
23 \% \text {, increased dFEV1 } \\
\text { by } 39 \% \text {, increased } \\
\text { FEF50 by } 33 \% \text {, } \\
\text { increased FEFmax by } \\
31 \%\end{array}$ \\
\hline & $\begin{array}{l}10 \text { subjects with } \\
\text { bronchial hyperactivity }\end{array}$ & $\mathrm{DA}$ IV $0.5 \mu \mathrm{g} / \mathrm{kg} / \mathrm{min}$ & No effect \\
\hline & 10 healthy subjects & $\mathrm{DA}$ IV $0.5 \mu \mathrm{g} / \mathrm{kg} / \mathrm{min}$ & No effect \\
\hline $\begin{array}{l}\text { Thomson et } \\
\text { al.[92] }\end{array}$ & $\begin{array}{l}12 \text { patients with extrinsic } \\
\text { bronchial asthma } \\
9 \text { normal subjects }\end{array}$ & $\begin{array}{l}\text { DA IV } 5 \mu \mathrm{g} / \mathrm{kg} / \mathrm{min} \\
\text { DA inhalation } 0.5 \mathrm{~g} / 1,1 \mathrm{~g} / \mathrm{l} \text { and } \\
2 \mathrm{~g} / 1\end{array}$ & $\begin{array}{l}\text { No effects on airway } \\
\text { resistance }\end{array}$ \\
\hline $\begin{array}{l}\text { Michoud et } \\
\text { al. } \\
\text { [31] }\end{array}$ & $\begin{array}{l}4 \text { healthy subjects } \\
4 \text { asthmatic subjects }\end{array}$ & $\begin{array}{l}\text { DA inhalation } \\
\text { DA infusion }\end{array}$ & $\begin{array}{l}\text { Significant decrease in } \\
\text { histamine- induced } \\
\text { bronchoconstriction }\end{array}$ \\
\hline \multirow{5}{*}{$\begin{array}{l}\text { Cabezas et } \\
\text { al. } \\
{[101]}\end{array}$} & 10 healthy subjects & DA inhalation $0.5 \mu \mathrm{g} / \mathrm{kg} / \mathrm{min}$ & $\begin{array}{l}\text { No changes in } \\
\text { respiratory parameters }\end{array}$ \\
\hline & $\begin{array}{l}10 \text { subjects with asthma } \\
\text { without acute } \\
\text { bronchospasm }\end{array}$ & $\mathrm{DA}$ inhalation $0.5 \mu \mathrm{g} / \mathrm{kg} / \mathrm{min}$ & $\begin{array}{l}\text { No changes in } \\
\text { respiratory parameters }\end{array}$ \\
\hline & $\begin{array}{l}9 \text { subjects with acute } \\
\text { asthma attack }\end{array}$ & $\mathrm{DA}$ inhalation $0.5 \mu \mathrm{g} / \mathrm{kg} / \mathrm{min}$ & $\begin{array}{l}\text { Increased FEV1, FVC, } \\
\text { FEFmax, FEF50 in }\end{array}$ \\
\hline & 10 healthy subjects & $\begin{array}{l}\text { Metoclopramide } \\
\mu \mathrm{g} / \mathrm{kg} / \mathrm{min}\end{array}$ & $\begin{array}{l}\text { No changes in } \\
\text { respiratory parameters }\end{array}$ \\
\hline & $\begin{array}{l}11 \text { subjects with asthma } \\
\text { without acute } \\
\text { bronchospasm }\end{array}$ & $\begin{array}{l}\text { Metoclopramide IV } \\
\mu \mathrm{g} / \mathrm{kg} / \mathrm{min}\end{array}$ & $\begin{array}{l}\text { No changes in } \\
\text { respiratory parameters }\end{array}$ \\
\hline
\end{tabular}

